illustrated by specific examples, and this practice is commended to the statesmen now gathered at Ottawa. The Right Hon. Lord Lugard explains the plan of the African Institute, with the financial support of the Rockefeller Foundation, to make a detailed study over a five-year period of the results of the impact of European civilisation upon the tribal system. Dr. H. V. Taylor, Commissioner of Horticulture to the Ministry of Agriculture, writes upon science and Empire fruit growing. The keynote of this article is that variation of climate, in the vast area covered by the Empire, prevents standardisation of methods, so that the grower is thrown into the hands of the research worker. Wool research in New Zealand and Empire air routes are other topics akin to the main theme which are also discussed.

\section{Acquisitions of the Natural History Museum}

A SERIES of microscope preparations showing all the early stages in the life history of the graptolite Climacograptus has been presented to the Department of Geology of the Natural History Museum by the Sedgwick Museum, Cambridge. The preparations were made by Mr. Ian Cox from material which he collected from rocks of Ordovician age in Akpatok Island, Ungava Bay, Northern Territory, Canada. Graptolites occur in the oldest fossiliferous rocks, and are organisms of unknown relationships, but generally supposed zoologically to resemble the living sea-firs, or sertularians-minute colonies of polyps encased in a horny skeleton. In the material from Akpatok Island, the original horny skeleton is preserved in a matrix of limestone, which can be dissolved and the skeleton extracted entire. The minutest structure and ornament of the early chambers, or thecæ, are visible, and the order and manner of budding of new thecæ can be clearly determined. Miss K. B. Macvicar has presented the extensive herbarium of her brother, Dr. Symers M. Macvicar, to the Department of Botany. Dr. Macvicar was the recognised British authority on Hepaticæ and was the author of the standard systematic account of them, "The Student's Handbook of British Hepatics". The herbarium is very rich in British and Continental species, and these are the more valuable because they are the basis of the descriptions and comparisons in the "Handbook". Dr. Macvicar was a medical man whose home was at Acharacle, Argyll, and in his travels in western Scotland accumulated an unrivalled representation of the flora, particularly of the less frequented parts of Argyll and Inverness. The herbarium contains about 18,000 specimens (that is, labels) and, as well as hepatics and flowering plants, contains mosses, seaweeds, and lichens. Mr. A. H. G. Alston, assistant keeper in the department, has just returned from western Greek Macedonia, where, in company with Mr. N. Y. Sandwith, of the Kew Herbarium, he spent six weeks. He collected about 1200 specimens, chiefly flowering plants. These are of interest because the area along the Albanian frontier has been visited previously only by a Czechoslovakian collector; moreover, the districts visited overlap to some extent those from which some plants were obtained by the department during the War.

\section{Protection of the Fauna and Flora of Poland}

If one may judge by the size and quality of Ochrona Pryyrody for 1931, the publication of the National Council for the Protection of Nature in Poland, a very vital interest is taken there in the preservation of natural amenities. The articles contain proposals for the formation of reserves for the primitive flora of the Dniester valley and elsewhere; but, perhaps because the position of some of the animals is more precarious, we turned to find out what measures were being discussed for their behoof. The opinion is held unanimously that the chase of the red deer of the Carpathians during the period of rut is harmful to the species and is responsible for the annual degeneration noticeable in the herds. But agreement is not reached as to the best means of meeting the difficulty. The majority hold as a distant ideal the desirability of suspending all hunting during the period of the rut, but since the custom is oldestablished and widespread, a gradual approach to the desirable end is suggested. An interesting paper by Wladyslaw Burzynski, the chief forester, discusses the position of the bear in the eastern Carpathians. The War was responsible for the slaughter of much of the breeding stock, so that even now the number probably does not exceed three hundred in an area of about 300,000 hectares. A third paper describes a visit to the workings and lodges of two colonies of beavers, one on the Szczara, the other on the Niemen.

\section{Research and the Wheat Quota}

SIR Albert Humphries, chairman of the National Institute of Agricultural Botany, in the course of his address to the annual meeting of the Institute's fellows at Cambridge on July 21 showed how agricultural research helps the farmer to make good use of the wheat quota. The quantity of wheat grown in Great Britain has been steadily diminishing and the proportion used for poultry has increased, so that in the past season home-grown wheat represented only some seven per cent of the national grist. The wheat quota is likely to raise this figure considerably, and the quality of English wheat for bread-making may come into its own again. The Cambridge Plant Breeding Institute has produced, and the National Institute of Agricultural Botany is now testing, a variety of which the quality is markedly superior even to Yeoman. Yielding capacity is, however, of first importance, and there are often differences of up to 20 per cent between varieties. The Institute in 1930 1931 tested, by methods which can detect much smaller differences, some hundred varieties, of which twenty are new ones not yet on the market. Sir Albert Humphries urged that facts of this sort show the Institute to be working directly for the improvement of the farmer's financial position,

\section{Courtauld Institute of Biochemistry}

The Courtauld Institute of Biochemistry of the Middlesex Hospital Medical School was given by $\mathbf{M r}$. S. A. Courtauld because the services of this depart. ment to the Hospital had inereased so greatly that it was impossible to house it in the Institute of

No. 3274 , VoL. 130] 